\title{
Officials' Rotation, Economic Growth and Environmental Accidents: Do They Affect the Political Promotion?
}

\author{
Yijun Dong \\ School of Economics, Jinan University, Guangzhou, China \\ Email: dongyijun1991@gmail.com
}

How to cite this paper: Dong, Y.J. (2016) Officials' Rotation, Economic Growth and Environmental Accidents: Do They Affect the Political Promotion? Modern Economy, 7, 1120-1133.

http://dx.doi.org/10.4236/me.2016.710112

Received: August 16, 2016

Accepted: September 11, 2016

Published: September 14, 2016

Copyright $\odot 2016$ by author and Scientific Research Publishing Inc. This work is licensed under the Creative Commons Attribution International License (CC BY 4.0).

http://creativecommons.org/licenses/by/4.0/ (c) (i) Open Access

\begin{abstract}
Using the rotation of Chinese officials based on handle-collected data from political process of provincial officials in China from 1992 to 2012, this paper examines the influence of officials' rotation, economic development and environmental accidents on the provincial officials' promotion probability. The results are as following: 1) officials' rotation and economic growth have a significant positive influence on the provincial officials' promotion probability, and the officials' rotation is more sensitive to the provincial officials' promotion probability. 2) Environmental accidents have a significant negative influence on the provincial officials' promotion. When three variables co-exist, the influence of economic development is not significant. 3) The results of different sub-samples based on the provincial officials' types and regions are different.
\end{abstract}

\section{Keywords}

Practice and Experience of Officials, Economic Growth, Social Stability, Political Promotion

\section{Introduction}

Since the reform and opening up, Chinese economy has continuously presented a rapid growth for 30 years. This phenomenon is called "Chinese growth miracle" or "China growth mode". Therefore, a large number of academic studies have devoted themselves to explaining it. For example, besides using a large number of new classical methods, such as capital (FDI), labor (demographic dividend and migrant workers), human capital (education), technology (R\&D) and so on, studies of government behavior have being flourishing, especially about officials' behaviors, in recent years. What's more, in 
terms of Chinese unique fiscal federalism and political promotion tournament, academics have reached a consensus that local officials play a very important role in Chinese rapid economic development and growth (Qian and Weingast, 1997 [1]; Qian and Roland, 1998 [2]; Jin et al., 2005 [3]; Li and Zhou, 2005 [4]; Xu et al., 2011 [5]; Opper et al., 2015 [6]; Jia et al., 2015 [7]).

As the "China's growth miracle" shown up, the traditional economic theory seems to be failed to explain the phenomenon. For example, natural resources, technological innovation and human capital are failed to make a reasonable explanation. Therefore, scholars began to focus on the "Chinese characteristic institution". Based on the great influence of the rising studies of new institutional economics and the famous researcher-C. North Douglass, the domestic and foreign scholars have committed them to research China's institution and economic growth. For example, Zhou $(2004,2007)$ studied the relationship between promotion of Chinese officials and economic growth which he named the "Promotion Tournament model" [8] [9]. Qianand Roland (1998) and Jin et al. (2005) believe that in the presence of current political and economic system of China, under the dual pattern of the administrative decentralization and fiscal decentralization, local officials are forced to compete for the GDP growth rate. To this end, scholars generally believe that GDP growth has become a very important criterion for local officials to get political promotion. However, Tao et al. (2010) found that in the empirical study, the average annual GDP growth rate and the annual mobile GDP growth rate of Chinese provincial local officials didn't influence their promotion significantly [10]. This paper found that the effect of average GDP growth rate on provincial officials' promotion was not significant, but for 4 years moving average GDP growth rate, the impact on political promotion was significant. To a certain extent, the central government prefers to promote officials who have done well recently.

This paper attempts to solve a problem as follow: Whether economic growth, official experience or environmental accidents eventually influence the promotion of Chinese provincial officials? In terms of local officials, the economic growth is of vital importance to political promotion. In addition, rotation of provincial officials is gradually institutionalized since 1992. The central government has always placed emphasis on the importance of reform, development and stability: the development is the purpose, the reform is the driving force, and the stability is the premise. The development emphasizes comprehensive development, but current literatures focus on using GDP growth rate to measure economic development. So there is a question about the economic growth and the rotation of provincial officials is that which one is more important for political promotion? At the same time, because of social stability it is wondering that whether economic growth and rotation of provincial officials will be affected?

The marginal contribution of this paper lies in: taking rotation of provincial officials and economic growth into consideration, this paper examines the impact of environmental accidents on the promotion probability of provincial officials. This is a supplement to researches of $\mathrm{Li}$ and Zhou (2005), Tao, et al. (2010) and Du, et al. (2012) [11]. This paper indicates that the effect of economic growth on the promotion of provincial 
officials is not significant after environmental accidents are controlled.

\section{Literature Review}

Based on the perspective of political system, Qian and Weingast (1997), Qian and Ronald (1998), Jin et al. (2005) as well as Wang (2007) explained Chinese rapid economic growth [12]. In view of Chinese special political institutions, the central government faced two incentives: one is fiscal decentralization, the other is administrative decentralization. Both of them together improved the efficiency of local government, and brought Chinese sustained rapid economic growth.

Zhang and Gao (2007) found that both provincial officials term limits and rotation of provincial officials have a positive effect over economic growth, and the relationship between officials' tenure and economic growth is inverted U-shaped [13]. Wang and $\mathrm{Xu}(2008)$ also found that some governors' economic performances in office existed an inverted U-shaped phenomenon [14]. Xu et al. (2007) found that the rotation of officials increased the economic growth rate of the local to $1 \%$ [15]. Wang and $\mathrm{Xu}$ (2009) found that at the years of rotation of officials, there are temporary negative shocks on local economic growth [16]. Xu and Wang (2010) found that the greater the official age, the weaker political incentive and the promotion effect of economic growth is smaller, but the extension of term made officials who faced bigger political incentives accelerate economic growth [17].

In addition to fiscal decentralization and administrative decentralization, Zhou (2007) believes that political promotion tournament model (local officials compete GDP growth for promotion) is a key point to understand the political incentives and local economic growth. Shleifer Blanchand (2000) and Maskin et al. (2002) pointed out that local officials in traditional bureaucrat level-structure particularly concerned about their political promotion [18] [19]. Zhou (2004) analyzed the impact of economic performance on the promotion of officials, and Li and Zhou (2005) in the empirical study confirmed that there is a significant positive correlation between provincial officials' promotion probability and GDP growth rate. Luo et al. (2015) which is a recent research with city level data confirmed that better economic growth significantly boosts the promotion probability of the secretary [20].

However, Tao et al. (2010) who questioned the inner logic of "Promotion Tournament" revealed that there isn't a significant positive correlation between provincial officials' promotion probability and GDP growth rate. Yao and Zhang (2013) found that local economic growth is not a good predictor for political promotion after politicians' personal effects are controlled [21].

As we can see, there exist contrary evidences which are about the different influence of economic performance on political promotion. Hence, this topic deserves further deeply research. What's more, environmental pollution is gradually getting worse and worse with the economic development. Central government of China is paying more and more attention on this field, because environmental accidents are relate to social stability which is very important for local officials' political promotion. According to 
former researches and my personal expectation, this paper will further discusses the effects of economic growth, rotation of provincial officials and environmental accidents on provincial officials' promotion probability.

\section{Theoretical Analysis and Hypothesis}

\subsection{Economic Growth and Promotion of Provincial Officials}

This is a common phenomenon in all countries that government officials are concerned about political promotion, especially in China. Huang (1996) pointed out that the relationship between the central government and local government is the core issue of Chinese reform and opening up [22]. In view of "Agency Problem", the complex relationship between the central government, agent of the people, and the local government, agent of the central government, is beyond our imagination. Under the condition that the formal institution is not perfect, how to "put the incentive to engage in" (Easterly, 2005) is essential to economic development [23]. This paper argues that in the process of provincial officials' performance assessment, the most obvious indicator, but also the most easily observed indicator is economic growth (GDP growth). So this paper put forward the following hypothesis 1 .

Hypothesis 1: Ceteris paribus, the GDP growth rate of provincial officials has a significant positive effect on their political promotion.

\subsection{Rotation and Promotion of Provincial Officials}

"Interim Provisions of the Party and Government Leading Cadres Exchange Work" showed clearly that cadres who had grass-roots work experience and outstanding achievements, should give priority to promotion. "Party and Government Leading Cadres and Leaders Exchange Work Regulations" further pointed out that "adhere to the combination of communication and training", "establish and improve cadres' exchange incentive mechanism". So this paper put forward the following hypothesis 2 .

Hypothesis 2: Ceteris paribus, rotation of provincial officials has a significant positive effect on their political promotion.

\subsection{Environmental Accidents and Promotion of Provincial Officials}

Social stability as a precondition is an important factor for development of society and economy. A spate of wars in the Middle East made its people live in misery, with the advantage of natural resources nothing left. Chinese special centralized institution makes the central government pay special attention to social stability. Maintenance is undoubtedly one of the most important objectives of the central government. Based on the principal-agent model, this goal will certainly pass through via some channels to the assessment system of local officials. To some extent, social problems occur because people can't stand. For example, there is a huge gap between local government behaviors and the local people's expectations. Environmental accidents are a source of tension because it is harmful to health. Under the assumption that the central government is "benevolent", the central government must reverse the preference of local govern- 
ment and officials so that their behaviors are accepted by people. So this paper put forward the following hypothesis 3 .

Hypothesis 3: Ceteris paribus, environmental accidents has a significant negative effect on the political promotion of provincial officials.

\section{Data and Model Design}

\subsection{Data}

The data of provincial governors and provincial Party Secretary from 1992 to 2012 are collected by hand. Our main data source is News of the Communist Party of China which is a website run by an official news agency-the People's Daily. It publishes Chinese Communist Party officials' curriculum vitae, especially some politicians who have held important positions. In addition, we also got some information from Wikipedia. As long as provincial officials are on duty between 1992 and 2012, they are included in our sample. What's more, officials who take office in 2012 before or after but didn't left by 2014 , will be drop from our sample.

Based on the People's daily and Xinhua daily, we searched provincial officials' curriculum vitae through some Encyclopedias, such as "Baidu Encyclopedia" and "Interactive Encyclopedia". The GDP data comes from "China Statistical Yearbook" and China Economic and Social Development Statistics Database. The data of environmental accidents come from the "China Environment Yearbook".

In the end, this paper got 322 observations, the provincial Party Secretary and governors are 158 and 164 respectively. Details are shown in Table 1.

Described in Table 1, gdprate denotes mean values of GDP growth rate, gdprate 3 denotes last 3 years' mean values of GDP growth rate before an official leaving office. The definition of gdprate 4 and gdprate 5 is similar to gdprate 3 .

During 1992 and 2012, the average tenure of the provincial officials was 4.59, less than a normal tenure (5 years), the average age was 56.41 . There are few differences in gdprate, gdprate 4 and gdprate 3 , but the closer to leaving office and the higher of mean values. If provincial officials expected rationally that they depart soon, then the incentive

Table 1. Descriptive statistics.

\begin{tabular}{cccccc}
\hline Variables & Count & Mean & SD & Max & Min \\
\hline Promotion & 322 & 0.41 & 0.49 & 1.00 & 0.00 \\
Age & 322 & 56.41 & 4.00 & 66.00 & 43.00 \\
Tenure & 322 & 4.59 & 2.40 & 15.00 & 1.00 \\
Gdprate & 322 & 11.26 & 2.40 & 19.88 & 5.08 \\
Gdprate 4 & 322 & 11.39 & 2.46 & 20.38 & 5.08 \\
Gdprate 3 & 322 & 11.51 & 2.56 & 20.77 & 5.10 \\
Environmental accidents & 318 & 54.69 & 70.40 & 340 & 0 \\
\hline
\end{tabular}

Source: Author's calculation using "China Statistical Yearbook", "China Environment Yearbook" and handed collected provincial officials data. 
role for provincial officials is stronger, we will capture higher mean values of GDP growth rate.

As can be seen from Table 2, most of the provincial officials took office aged between 55 and 59, accounting for $47.68 \%$. During the age between 50 and 54, the officials' promotion ratio is higher, reaching to $48.75 \%$. As can be seen from Table 3 , the tenure of the provincial officials is between 3 and 5 years, accounting for $64.29 \%$, generally shorter than a normal term. Most officials were promoted to a higher position when their term is shorter than 5 years. But when their term is $9-10$ years, the probability of promotion will surge. The reason is that provincial officials must be exchanged when they up to two terms. If officials, who holding the second term, are unable to be exchanged which means their political career come to end. So under such situation, promotion incentives of provincial officials are extremely strong, they will be dedicated to the economic growth.

\subsection{Model Design}

In order to test hypothesis $1,2,3$, this paper constructed the LPM model:

$$
\begin{aligned}
\text { promotion }_{i}= & \beta_{0}+\beta_{1} \text { pcgdp }_{i t-1}+\beta_{2} \text { gdprate }_{i}+\beta_{3} \text { tenure }_{i} \\
& +\beta_{4} \text { age }_{i}+\beta_{5} \text { llzs }_{i}+\beta_{6} x_{i}+\gamma_{p}+\varepsilon_{i}
\end{aligned}
$$

Table 2. Analysis of age.

\begin{tabular}{cccccc}
\hline \multirow{2}{*}{ Age } & \multicolumn{2}{c}{ Observations } & \multicolumn{3}{c}{ Observations of promotion } \\
\cline { 2 - 6 } & Num 1 & Rate 1 & Num 2 & Num 2/Num 1 & Rate 2 \\
\hline $40-44$ & 2 & $0.62 \%$ & 2 & $100 \%$ & $1.5 \%$ \\
$45-49$ & 16 & $4.95 \%$ & 12 & $75 \%$ & $9.02 \%$ \\
$50-54$ & 80 & $24.77 \%$ & 39 & $48.75 \%$ & $29.32 \%$ \\
$55-59$ & 154 & $47.68 \%$ & 60 & $38.96 \%$ & $45.11 \%$ \\
$60-64$ & 70 & $21.67 \%$ & 19 & $27.14 \%$ & $14.29 \%$ \\
$65-69$ & 1 & $0.31 \%$ & 1 & $100 \%$ & $0.75 \%$ \\
Total & 322 & $100 \%$ & 133 & & $100 \%$ \\
\hline
\end{tabular}

Source: Author's calculation using handed collected provincial officials data.

Table 3. Analysis of tenure.

\begin{tabular}{cccccc}
\hline \multirow{2}{*}{$\begin{array}{c}\text { Tenure } \\
\text { (years) }\end{array}$} & \multicolumn{2}{c}{ Observations } & \multicolumn{3}{c}{ Observations of promotion } \\
\cline { 2 - 5 } & Num 3 & Rate 3 & Num 4 & Num 4/Num 3 & Rate 4 \\
\hline $1-2$ & 55 & $17.08 \%$ & 28 & $50.91 \%$ & $21.05 \%$ \\
$3-4$ & 119 & $36.96 \%$ & 52 & $43.70 \%$ & $39.10 \%$ \\
$5-6$ & 88 & $27.33 \%$ & 38 & $43.18 \%$ & $28.57 \%$ \\
$7-8$ & 36 & $11.18 \%$ & 6 & $16.67 \%$ & $4.51 \%$ \\
$9-10$ & 18 & $5.59 \%$ & 7 & $38.89 \%$ & $5.26 \%$ \\
$11-15$ & 6 & $1.86 \%$ & 2 & $33.33 \%$ & $1.50 \%$ \\
Total & 322 & $100 \%$ & 133 & & $100 \%$ \\
\hline
\end{tabular}

Source: Author's calculation using handed collected provincial officials data. 
Variables of this model are defined as follows:

1) promotion $_{i}$ is a dummy that whether provincial official $i$ was promoted or not, if a provincial official was promoted, its value is 1 , otherwise it is 0 . Promotion criteria of provincial officials are defined as follows: after leaving office for the provincial Party Secretary, if they were transferred to the municipality directly under the central government as a mayor or the secretary of municipal Party Committee, vice chairman of the Standing Committee of the National People's Congress, vice chairman of the CPPCC National Committee, Secretary of the Secretariat of the CPC Central Committee, vice premier of the State Council, vice president, director of the general office of the CPC Central Committee, the Central Political Bureau and a member of the Standing Committee, State Councilor and Central Military Commission headquarters of the four chief, the State Council Deputy Secretary General and so on or to above positions, I will view this a promotion behavior. After leaving office, if governors were transferred to the provincial party secretary or any position mentioned above, I will view this as a promotion behavior too.

2) $p c g d p_{i, t-1}$ denotes real GDP per capita a year before a provincial official $i$ took charge so as to control the initial economic development level of each province. gdprate denotes mean values of GDP growth rate, last 4 years' mean values of GDP growth rate before an official leaving office, or last 3 years' mean values of GDP growth rate before an official leaving office, in order to examine whether the central government pays more attention to the current economic situation. $1 l z s_{i}$ is a dummy that whether an official ever worked in other provinces, remote areas, central government or state-owned enterprises. $\gamma_{p}$ is a dummy of provinces.

3) $x_{i}$ represents the average number of environmental accidents.

\section{Empirical Findings}

\subsection{Rotation, Economic Growth and Promotion of Provincial Officials}

As we can see in Table 4, regress political promotion on economic growth and provincial officials' experience index (the inter-provincial work experience, the central work experience, the remote areas work experience and the SOEs work experience respectively). We find in column 1 inter-provincial work experience (inter-province), and column 5 officials' exchange experience index (llzs) are both significant at $1 \%$ level, coefficient is $0.165,0.115$, respectively. What's more, both of them are positive which is in line with our expectation and hypothesis 2 .

Both age and tenure of provincial officials have significant negative effect on political promotion. Both of them are significant at $1 \%$ level, and values of coefficient are 0.036 , 0.040 , respectively.

In all six columns, mean values of GDP growth rate (gdprate) are not statistically significant, while symbols of the coefficient are positive.

In this paper, the GDP growth rate which is shown in Table 5 was transformed into 4 types. The other 3 types include gdprate 3, gdprate 4 and gdprate 5, all of them are explained before. Other variables were identical to Table 4 , and the coefficient of 
Table 4. Rotation, economic growth and promotion of provincial officials.

\begin{tabular}{|c|c|c|c|c|c|c|}
\hline \multirow{2}{*}{$\begin{array}{l}\text { Independent } \\
\text { variables }\end{array}$} & \multicolumn{6}{|c|}{ Dependent variable: promotion (total samples) } \\
\hline & (1) & (2) & (3) & (4) & $(5)$ & (6) \\
\hline \multirow[t]{2}{*}{ inter-province } & $0.165^{\star * *}$ & & & & & $0.174^{* * *}$ \\
\hline & $(0.059)$ & & & & & $(0.062)$ \\
\hline \multirow[t]{2}{*}{ central } & & -0.027 & & & & -0.047 \\
\hline & & $(0.065)$ & & & & $(0.066)$ \\
\hline \multirow[t]{2}{*}{ remote } & & & 0.009 & & & -0.036 \\
\hline & & & $(0.081)$ & & & $(0.082)$ \\
\hline \multirow[t]{2}{*}{ enterprise } & & & & -0.032 & & -0.024 \\
\hline & & & & $(0.060)$ & & $(0.062)$ \\
\hline \multirow[t]{2}{*}{ llzs } & & & & & $0.115^{\star * \star}$ & \\
\hline & & & & & $(0.034)$ & \\
\hline \multirow{2}{*}{ gdprate } & 0.021 & 0.019 & 0.020 & 0.019 & 0.020 & 0.020 \\
\hline & $(0.014)$ & $(0.014)$ & $(0.014)$ & $(0.014)$ & $(0.013)$ & $(0.014)$ \\
\hline \multirow{2}{*}{$p c g d p_{t-1}$} & $0.000^{* *}$ & $0.000^{\star * *}$ & $0.000^{* * *}$ & $0.000^{\star *}$ & $0.000^{*}$ & $0.000^{\star *}$ \\
\hline & $(0.000)$ & $(0.000)$ & $(0.000)$ & $(0.000)$ & $(0.000)$ & $(0.000)$ \\
\hline \multirow[t]{2}{*}{ tenure } & $-0.035^{\star *}$ & $-0.039^{* * *}$ & $-0.039^{* * *}$ & $-0.039^{* * *}$ & $-0.034^{* *}$ & $-0.036^{* * *}$ \\
\hline & $(0.014)$ & $(0.014)$ & $(0.014)$ & $(0.014)$ & $(0.014)$ & $(0.014)$ \\
\hline \multirow[t]{2}{*}{ age } & $-0.039^{\star * *}$ & $-0.038^{\star * *}$ & $-0.038^{\star * *}$ & $-0.038^{\star * *}$ & $-0.040^{* * *}$ & $-0.040^{* * *}$ \\
\hline & $(0.007)$ & $(0.007)$ & $(0.007)$ & $(0.007)$ & $(0.007)$ & $(0.007)$ \\
\hline $\begin{array}{l}\text { dummy of } \\
\text { provinces }\end{array}$ & YES & YES & YES & YES & YES & YES \\
\hline \multirow[t]{2}{*}{ _cons } & 0.198 & 0.473 & 0.411 & 0.494 & 0.223 & 0.365 \\
\hline & (1.582) & $(1.631)$ & $(1.628)$ & (1.637) & $(1.551)$ & (1.605) \\
\hline$N$ & 295 & 295 & 295 & 295 & 295 & 295 \\
\hline
\end{tabular}

Source: Author's calculation using STATA 13.1. Robust standard errors in parentheses, ${ }^{*} p<0.10,{ }^{* *} p<0.05,{ }^{* * *} p<$ 0.01 .

gdprate was not significant. But the coefficient of gdprate 4 is significant positive at $10 \%$ level, the value is 0.023 . The coefficient of gdprate 3 is significant positive at $5 \%$ level, the value is 0.024 . In Sample 1 and Sample 2, empirical results are similar to the Total Samples.

\subsection{Rotation, Economic Growth, Environmental Accidents and Promotion of Provincial Officials}

This paper takes environmental accidents as a proxy variable of social stability. And environmental accidents denote the average value of the number of environmental incidents occurred during a term. On the basis of the whole sample, there are five subsamples which are the provincial Party Secretary, provincial governors, east, central and west of China (see Table 6 and Table 7 for details). We find that, in general, environmental accidents $(\mathrm{x})$ have a significant negative impact on the promotion of provincial 
Table 5. Rotation, economic growth and promotion of provincial officials.

\begin{tabular}{|c|c|c|c|c|c|c|}
\hline \multirow{3}{*}{$\begin{array}{l}\text { Independent } \\
\text { variables }\end{array}$} & \multicolumn{6}{|c|}{ Dependent variable: promotion } \\
\hline & \multicolumn{4}{|c|}{ Total Samples } & \multirow{2}{*}{$\begin{array}{c}\text { Sample } 1 \\
(5)\end{array}$} & \multirow{2}{*}{$\begin{array}{c}\text { Sample } 2 \\
(6)\end{array}$} \\
\hline & (1) & (2) & (3) & (4) & & \\
\hline \multirow{2}{*}{ gdprate } & 0.020 & & & & & $0.033^{*}$ \\
\hline & $(0.014)$ & & & & & $(0.019)$ \\
\hline \multirow{2}{*}{ gdprate 5} & & 0.022 & & & & \\
\hline & & $(0.013)$ & & & & \\
\hline \multirow{2}{*}{ gdprate 4} & & & $0.023^{*}$ & & & \\
\hline & & & $(0.013)$ & & & \\
\hline \multirow{2}{*}{ gdprate 3} & & & & $0.024^{* *}$ & 0.016 & \\
\hline & & & & $(0.012)$ & $(0.017)$ & \\
\hline Inter- & $0.174^{* * *}$ & $0.175^{\star * *}$ & $0.177^{\star * *}$ & $0.179^{* * *}$ & $0.200^{* *}$ & 0.103 \\
\hline province & $(0.062)$ & $(0.062)$ & $(0.062)$ & $(0.062)$ & $(0.086)$ & $(0.108)$ \\
\hline \multirow[t]{2}{*}{ central } & -0.047 & -0.045 & -0.044 & -0.041 & 0.015 & -0.084 \\
\hline & $(0.066)$ & $(0.066)$ & $(0.066)$ & $(0.065)$ & $(0.090)$ & $(0.106)$ \\
\hline \multirow[t]{2}{*}{ remote } & -0.036 & -0.036 & -0.036 & -0.038 & 0.035 & 0.023 \\
\hline & $(0.082)$ & $(0.082)$ & $(0.082)$ & $(0.082)$ & $(0.118)$ & $(0.145)$ \\
\hline \multirow[t]{2}{*}{ enterprise } & -0.024 & -0.024 & -0.025 & -0.029 & 0.055 & -0.010 \\
\hline & $(0.062)$ & $(0.062)$ & $(0.061)$ & $(0.062)$ & $(0.083)$ & $(0.095)$ \\
\hline \multirow{2}{*}{$p c g d p_{t-1}$} & $0.000^{* *}$ & $0.000^{* *}$ & $0.000^{* *}$ & $0.000^{* *}$ & $0.000^{*}$ & 0.000 \\
\hline & $(0.000)$ & $(0.000)$ & $(0.000)$ & $(0.000)$ & $(0.000)$ & $(0.000)$ \\
\hline \multirow[t]{2}{*}{ tenure } & $-0.036^{\star * *}$ & $-0.037^{* * *}$ & $-0.036^{* * *}$ & $-0.036^{\star * *}$ & $-0.029^{\star}$ & -0.034 \\
\hline & $(0.014)$ & $(0.014)$ & $(0.014)$ & $(0.014)$ & $(0.017)$ & $(0.022)$ \\
\hline \multirow[t]{2}{*}{ age } & $-0.040^{\star * *}$ & $-0.040^{* * *}$ & $-0.039^{* * *}$ & $-0.039^{* * *}$ & $-0.037^{* * *}$ & -0.019 \\
\hline & $(0.007)$ & $(0.007)$ & $(0.007)$ & $(0.007)$ & $(0.010)$ & $(0.013)$ \\
\hline $\begin{array}{l}\text { dummy of } \\
\text { province }\end{array}$ & YES & YES & YES & YES & YES & YES \\
\hline \multirow[t]{2}{*}{ _cons } & 0.365 & 0.145 & -0.018 & -0.175 & 0.323 & -2.032 \\
\hline & $(1.605)$ & (1.578) & $(1.550)$ & $(1.431)$ & (2.095) & (2.217) \\
\hline$N$ & 295 & 295 & 295 & 295 & 141 & 154 \\
\hline
\end{tabular}

Source: Author's calculation using STATA 13.1. Sample 1 denotes sample of Secretary of the provincial Party Committee, Sample 2 denotes sample of Governor of Province. Robust standard errors in parentheses, ${ }^{\star} p<0.10,{ }^{\star *} p<$ $0.05,{ }^{* * *} p<0.01$.

officials.

Showed at Table 6, the first and second column is full sample regressions. When environmental accidents variable is added in regression, the coefficient of inter-provincial work experience is still significant positive at the $1 \%$ level. But GDP growth rate has no significant effect on the promotion of provincial officials, even though using gdprate 3 . However, the coefficients of environmental accidents, which are respectively shown in the first and the second column, were significant negative at the level of $10 \%$. 
Table 6. Rotation, economic growth, environmental accidents and promotion of provincial officials.

\begin{tabular}{|c|c|c|c|c|c|c|}
\hline \multirow{3}{*}{ Dependent variables } & \multicolumn{6}{|c|}{ Dependent variable: promotion } \\
\hline & \multicolumn{2}{|c|}{ Total samples } & \multicolumn{2}{|c|}{ Sample 1} & \multicolumn{2}{|c|}{ Sample 2} \\
\hline & (1) & (2) & (3) & (4) & (5) & (6) \\
\hline \multirow{2}{*}{ gdprate 4} & 0.017 & & 0.023 & & 0.009 & \\
\hline & $(0.017)$ & & $(0.022)$ & & $(0.024)$ & \\
\hline \multirow{2}{*}{ gdprate 3} & & 0.018 & & 0.024 & & 0.012 \\
\hline & & $(0.016)$ & & $(0.020)$ & & $(0.024)$ \\
\hline \multirow{2}{*}{$p c g d p_{t-1}$} & 0.000 & 0.000 & 0.000 & 0.000 & 0.000 & 0.000 \\
\hline & $(0.000)$ & $(0.000)$ & $(0.000)$ & $(0.000)$ & $(0.000)$ & $(0.000)$ \\
\hline \multirow[t]{2}{*}{ inter-province } & $0.215^{\star * *}$ & $0.216^{\star * *}$ & $0.331^{\star * *}$ & $0.331^{\star * *}$ & 0.116 & 0.119 \\
\hline & $(0.068)$ & $(0.068)$ & $(0.098)$ & $(0.097)$ & $(0.122)$ & $(0.122)$ \\
\hline \multirow[t]{2}{*}{$\mathbf{x}$} & $-0.002^{\star}$ & $-0.002^{\star}$ & -0.001 & -0.001 & $-0.003^{\star * \star}$ & $-0.003^{\star * *}$ \\
\hline & $(0.001)$ & $(0.001)$ & $(0.002)$ & $(0.002)$ & $(0.001)$ & $(0.001)$ \\
\hline \multirow[b]{2}{*}{$x_{t-1}$} & 0.001 & 0.001 & -0.000 & -0.000 & 0.001 & 0.001 \\
\hline & $(0.001)$ & $(0.001)$ & $(0.001)$ & $(0.001)$ & $(0.001)$ & $(0.001)$ \\
\hline \multirow[t]{2}{*}{ tenure } & $-0.041^{\star * *}$ & $-0.041^{* * *}$ & -0.020 & -0.021 & -0.040 & -0.040 \\
\hline & $(0.016)$ & $(0.016)$ & $(0.019)$ & $(0.019)$ & $(0.028)$ & $(0.028)$ \\
\hline \multirow[t]{2}{*}{ age } & $-0.035^{\star * \star}$ & $-0.035^{\star * *}$ & $-0.029^{\star * *}$ & $-0.029^{* * *}$ & -0.012 & -0.012 \\
\hline & $(0.007)$ & $(0.007)$ & $(0.011)$ & $(0.010)$ & $(0.014)$ & $(0.014)$ \\
\hline dummy of provinces & YES & YES & YES & YES & YES & YES \\
\hline \multirow[t]{2}{*}{ _cons } & 0.412 & 0.230 & -0.987 & -1.080 & 0.303 & 0.008 \\
\hline & $(1.992)$ & $(1.851)$ & $(2.638)$ & $(2.439)$ & $(2.802)$ & $(2.763)$ \\
\hline$N$ & 243 & 243 & 118 & 118 & 125 & 125 \\
\hline
\end{tabular}

Source: Author's calculation using STATA 13.1. Sample 1 denotes subsample of Secretary of the provincial Party Committee, Sample 2 denotes subsample of Governor of Province. Robust standard errors in parentheses, ${ }^{*} p<0.10$, ${ }^{* *} p<0.05,{ }^{* * *} p<0.01$.

Sample 1 denotes subsample of the Secretary of the provincial Party Committee, Sample 2 denotes subsample of governors. According to the third and fourth column, this paper shows that both mean values of GDP growth rate and environmental accidents do not exist significant influence on political promotion. Inter-provincial work experience and age both have a significant effect on promotion. In the fifth and sixth column, this paper find that all of mean values of GDP growth rate, the inter-provincial work experience of governors, age and tenure had no significant influence on promotion of governors, but environmental accidents have a significant negative effect on promotion of governors at level of $1 \%$, the coefficient is -0.003 .

Table 7 is regional subsample regression, both mean values of GDP growth rate and environmental accidents have no significant effect on promotion of provincial officials. While inter-provincial work experience, age and tenure of provincial officials exist significant influence on political promotion. In terms of provincial officials in the eastern 
Table 7. Rotation, economic growth, environmental accidents and promotion of provincial officials.

\begin{tabular}{|c|c|c|c|c|c|c|}
\hline \multirow{3}{*}{ Dependent variables } & \multicolumn{6}{|c|}{ Dependent variable: promotion } \\
\hline & \multicolumn{2}{|c|}{ Total samples } & \multicolumn{2}{|c|}{ East } & \multicolumn{2}{|c|}{ Central and West } \\
\hline & (1) & (2) & (3) & $(4)$ & (5) & (6) \\
\hline \multirow{2}{*}{ gdprate 4} & 0.017 & & 0.030 & & 0.012 & \\
\hline & $(0.017)$ & & $(0.026)$ & & $(0.024)$ & \\
\hline \multirow{2}{*}{ gdprate 3} & & 0.018 & & 0.037 & & 0.013 \\
\hline & & $(0.016)$ & & $(0.024)$ & & $(0.022)$ \\
\hline \multirow{2}{*}{$p c g d p_{t-1}$} & 0.000 & 0.000 & $0.000^{*}$ & $0.000^{*}$ & 0.000 & 0.000 \\
\hline & $(0.000)$ & $(0.000)$ & $(0.000)$ & $(0.000)$ & $(0.000)$ & $(0.000)$ \\
\hline \multirow[t]{2}{*}{ inter-province } & $0.215^{\star * *}$ & $0.216^{* * *}$ & $0.281^{* *}$ & $0.286^{* *}$ & $0.183^{* *}$ & $0.184^{* *}$ \\
\hline & $(0.068)$ & $(0.068)$ & $(0.122)$ & $(0.122)$ & $(0.083)$ & $(0.083)$ \\
\hline \multirow{2}{*}{$\mathbf{x}$} & $-0.002^{\star}$ & $-0.002^{\star}$ & -0.003 & -0.003 & -0.002 & -0.002 \\
\hline & $(0.001)$ & $(0.001)$ & $(0.002)$ & $(0.002)$ & $(0.001)$ & $(0.001)$ \\
\hline \multirow{2}{*}{$x_{t-1}$} & 0.001 & 0.001 & 0.003 & 0.003 & 0.000 & 0.000 \\
\hline & $(0.001)$ & $(0.001)$ & $(0.002)$ & $(0.002)$ & $(0.001)$ & $(0.001)$ \\
\hline \multirow[t]{2}{*}{ tenure } & $-0.041^{* * *}$ & $-0.041^{* * *}$ & -0.016 & -0.014 & $-0.049^{\star *}$ & $-0.049^{\star *}$ \\
\hline & $(0.016)$ & $(0.016)$ & $(0.029)$ & $(0.029)$ & $(0.019)$ & $(0.019)$ \\
\hline \multirow[t]{2}{*}{ age } & $-0.035^{\star * *}$ & $-0.035^{\star * *}$ & $-0.038^{\star * *}$ & $-0.038^{\star * *}$ & $-0.033^{* * *}$ & $-0.033^{* * *}$ \\
\hline & $(0.007)$ & $(0.007)$ & $(0.012)$ & $(0.012)$ & $(0.010)$ & $(0.010)$ \\
\hline dummy of province & YES & YES & YES & YES & YES & YES \\
\hline \multirow[t]{2}{*}{ _cons } & 0.412 & 0.230 & -1.166 & -1.907 & 1.012 & 0.909 \\
\hline & $(1.992)$ & $(1.851)$ & $(3.124)$ & $(2.903)$ & $(2.718)$ & $(2.493)$ \\
\hline$N$ & 243 & 243 & 86 & 86 & 157 & 157 \\
\hline
\end{tabular}

Source: Author's calculation using STATA 13.1. Robust standard errors in parentheses, ${ }^{*} p<0.10,{ }^{* *} p<0.05,{ }^{* * *} p<$ 0.01 .

region, the impact is not significant.

\section{Robust Check}

In this paper, we use the logit model to check robustness of our empirical results.

$$
\begin{aligned}
\text { promotion }_{i}=\ln \left(\frac{p}{1-p}\right)= & \alpha_{0}+\alpha_{1} \text { pcgdp }_{i t-1}+\alpha_{2} \text { gdprate }_{i}+\alpha_{3} \text { tenure }_{i} \\
& +\alpha_{4} \text { age }_{i}+\alpha_{5} \text { llzs }_{i}+\alpha_{6} x_{i}+\gamma_{p}+\varepsilon_{i}
\end{aligned}
$$

In this model, variables are same with above and explained in the LPM model. As we can see in Table 8, empirical results show that the logit model does not change coefficients and symbols of the key variables significantly.

\section{Conclusions}

Specifically, this paper indicates that: 1) officials' rotation and economic growth have a significant positive influence on the provincial officials' promotion probability, and the 
Table 8. Logit model.

\begin{tabular}{|c|c|c|c|c|c|c|c|}
\hline \multirow{3}{*}{$\begin{array}{l}\text { Independent } \\
\text { variables }\end{array}$} & \multicolumn{7}{|c|}{ Dependent variable: promotion } \\
\hline & \multicolumn{3}{|c|}{ Total samples } & \multirow{2}{*}{$\begin{array}{c}\text { Sample } 1 \\
(4)\end{array}$} & \multirow{2}{*}{$\begin{array}{c}\text { Sample } 2 \\
(5)\end{array}$} & \multicolumn{2}{|c|}{ East Central and Wes } \\
\hline & (1) & (2) & (3) & & & (6) & (7) \\
\hline \multirow[t]{2}{*}{ gdprate 4} & $0.113^{\star}$ & 0.096 & & & 0.053 & $0.269^{\star}$ & \\
\hline & $(0.066)$ & $(0.085)$ & & & $(0.117)$ & $(0.147)$ & \\
\hline \multirow[t]{2}{*}{ gdprate 3} & & & 0.104 & 0.249 & & & 0.062 \\
\hline & & & $(0.080)$ & $(0.220)$ & & & $(0.102)$ \\
\hline \multirow[t]{2}{*}{ inter-province } & $1.015^{\star * *}$ & $1.200^{* * *}$ & $1.208^{\star * *}$ & $3.474^{* *}$ & 0.712 & $1.815^{* *}$ & $1.006^{* *}$ \\
\hline & $(0.335)$ & $(0.374)$ & $(0.374)$ & $(1.395)$ & $(0.582)$ & $(0.749)$ & $(0.448)$ \\
\hline \multirow[t]{2}{*}{ central } & -0.215 & & & & & & \\
\hline & $(0.326)$ & & & & & & \\
\hline \multirow[t]{2}{*}{ remote } & -0.158 & & & & & & \\
\hline & $(0.373)$ & & & & & & \\
\hline \multirow[t]{2}{*}{ enterprise } & -0.182 & & & & & & \\
\hline & $(0.325)$ & & & & & & \\
\hline \multirow[t]{3}{*}{$x$} & & $-0.010^{\star}$ & -0.009 & -0.001 & $-0.023^{* * *}$ & $-0.021^{\star}$ & -0.008 \\
\hline & & $(0.006)$ & $(0.006)$ & $(0.011)$ & $(0.008)$ & $(0.013)$ & $(0.006)$ \\
\hline & & & $p=0.102$ & & & & \\
\hline \multirow[t]{2}{*}{$x_{t-1}$} & & 0.006 & 0.006 & -0.014 & 0.011 & $0.020^{* *}$ & 0.001 \\
\hline & & $(0.005)$ & $(0.005)$ & $(0.014)$ & $(0.008)$ & $(0.010)$ & $(0.006)$ \\
\hline \multirow[t]{2}{*}{$p c g d p_{t-1}$} & $0.000^{* *}$ & $0.000^{*}$ & $0.000^{*}$ & 0.000 & 0.000 & $0.000^{* *}$ & 0.000 \\
\hline & $(0.000)$ & $(0.000)$ & $(0.000)$ & $(0.000)$ & $(0.000)$ & $(0.000)$ & $(0.000)$ \\
\hline \multirow[t]{2}{*}{ tenure } & $-0.208^{\star * *}$ & $-0.238^{\star \star}$ & $-0.237^{\star *}$ & -0.175 & $-0.314^{\star}$ & -0.102 & $-0.268^{\star *}$ \\
\hline & $(0.077)$ & $(0.094)$ & $(0.094)$ & $(0.233)$ & $(0.167)$ & $(0.184)$ & $(0.110)$ \\
\hline \multirow[t]{2}{*}{ age } & $-0.213^{* * *}$ & $-0.183^{* * *}$ & $-0.183^{* * *}$ & $-0.299^{* * *}$ & -0.055 & $-0.243^{* * *}$ & $-0.169^{* * *}$ \\
\hline & $(0.043)$ & $(0.043)$ & $(0.043)$ & $(0.093)$ & $(0.069)$ & $(0.077)$ & $(0.056)$ \\
\hline $\begin{array}{l}\text { dummy of } \\
\text { provinces }\end{array}$ & YES & YES & YES & YES & YES & YES & YES \\
\hline \multirow[t]{2}{*}{ _cons } & -1.436 & -1.344 & -2.303 & -14.855 & -1.575 & -19.108 & 2.268 \\
\hline & $(7.834)$ & $(9.851)$ & $(9.270)$ & $(25.145)$ & $(13.437)$ & $(16.821)$ & (11.712) \\
\hline$N$ & 295 & 235 & 235 & 81 & 108 & 86 & 149 \\
\hline
\end{tabular}

Source: Author's calculation using STATA 13.1. Robust standard errors in parentheses, ${ }^{*} p<0.10,{ }^{* *} p<0.05,{ }^{* * *} p<$ 0.01 .

officials' rotation is more sensitive to the provincial officials' promotion probability. 2) Environmental accidents have a significant negative influence on the provincial officials' promotion. When three variables co-exist, the influence of economic development is not significant. 3) The results of different sub-samples based on the provincial officials' types and regions are different.

As described above, based on last 3 or 4 years' regional economic performance (GDP 
growth rate) before an official leaving office, the central government made its political decision for provincial officials. The average tenure of provincial officials in the sample is 4.59 years, shorter than a normal term. In view of these common phenomena, provincial officials who have rational expectation for their own tenure would likely to take short-sighted polices. At the expense of the economic and social resources, we achieve better economic performance. However, this is not conducive to regional sustained and healthy economic development, but will inevitably be detrimental to the long-term welfare of residents. For example, health care, education, and environmental governance can't be achieved in the short term. In view of officials' "selective neglect" behaviors, the progress of life quality will fall behind the industrialization process, and it will inevitably make social conflicts continue to intensify. As a result of many welfare indicators can't be quantified, the assessment systems of central government reply on quantitative indicators heavily. We see that the environmental incidents indeed affect promotion of provincial officials, however, the impact is very small. Due to the difficulty of data collection and quantifying social stability, it is difficult to fully assess the impact of social stability on promotion probability of the provincial officials.

\section{References}

[1] Qian, Y.Y. and Weingast, B.R. (1997) Federalism as a Commitment to Preserving Market Incentives. Journal of Economic Perspectives, 11, 83-92. http://dx.doi.org/10.1257/jep.11.4.83

[2] Qian, Y.Y. and Roland, G. (1998) Federalism and the Soft Budget Constraint. American Economic Review, 88, 1143-1162.

[3] Jin, H.H., Qian, Y.Y. and Weingast, B.R. (2005) Regional Decentralization and Fiscal Incentives: Federalism, China Style. Journal of Public Economics, 89, 1719-1742. http://dx.doi.org/10.1016/j.jpubeco.2004.11.008

[4] Li, H.B. and Zhou, L.A. (2005) Political Turnover and Economic Performance: The Incentive Role of Personnel Control in China. Journal of Public Economics, 89, 1743-1762. http://dx.doi.org/10.1016/j.jpubeco.2004.06.009

[5] Xu, C.G. (2011) The Fundamental Institutions of China's Reforms and Development. Journal of Economic Literature, 49, 1076-1151. http://dx.doi.org/10.1257/jel.49.4.1076

[6] Opper, S., Nee, V. and Brehm, S. (2015) Homophily in the Career Mobility of China's Political Elite. Social Science Research, 54, 332-352. http://dx.doi.org/10.1016/j.ssresearch.2015.08.007

[7] Jia, R., Kudamatsu, M. and Seim, D. (2015) Political Selection in China: The Complementary Roles of Connections and Performance. Journal of the European Economic Association, 13, 631-668. http://dx.doi.org/10.1111/jeea.12124

[8] Zhou, L.A. (2004) The Incentive and Cooperation of Government Officials in Political Tournaments: An Interpretation of the Prolonged Local Protectionism and Duplicative Investments in China. Economic Research Journal, 6, 33-40.

[9] Zhou, L.A. (2007) Governing China's Local Officials: An Analysis of Promotion Tournament Model. Economic Research Journal, 7, 36-50.

[10] Tao, R., Su, F.B., Lu, X. and Zhu, Y.M. (2010) Does Economic Growth Lead to Promotion? A Challenge of the Logic of Tournaments and Reevaluation of Provincial-level Data. Management World, 12, 13-26. 
[11] Du, X.Q., Zeng, Q. and Wu, J.W. (2012) Rotation, Economic Development and Political Promotion. Journal of Financial Research, 2, 30-47.

[12] Wang, Y.Q., Zhang, Y., Zhang, Y., Chen, Z., and Lu, M. (2007) On China's Development Model: The Costs and Benefits of China's Decentralization Approach to Transition. Economic Research Journal, 1, 4-16.

[13] Zhang, J. and Gao, Y. (2007) Term Limits and Rotation of Chinese Governors: Do They Matter to Economic Growth? Economic Research Journal, 11, 91-103.

[14] Wang, X.B. and Xu, X.X. (2008) Before and after Position, Tenure and Economic Growth: Evidence from Provincial Officials of China. Management World, 3, 16-26.

[15] Xu, X.X., Wang, X.B. and Shu, Y. (2007) Local Officials and Economic Growth. Economic Research Journal, 9, 18-31.

[16] Wang, X.B. and Xu, X.X. (2009) On the Development Behavior of Local Officials in China: An Analysis based on Political Incentive and Federalism. Nankai Economic Studies, 2, 58-79.

[17] Xu, X.X. and Wang, X.B. (2010) Political Promotion Incentive and Economic Growth: Evidence from Provincial Officials of China. The Journal of World Economy, 2, 15-36.

[18] Blanchard, O. and Shleifer, A. (2000) Federalism With and Without Political Centralization: China versus Russia. NBER, No. 7616. http://dx.doi.org/10.2139/ssrn.236127

[19] Mankiw, N.D., Romer, D. and Weil, D.N. (1992) A Contribution to the Empirics of Economic Growth. Quarterly Journal of Economics, 107, 407-437. http://dx.doi.org/10.2307/2118477

[20] Luo D.L., She G.M. and Chen J. (2015) A New Re-Examination of the Relationship between Economic Performance and Local Leader' Promotion: New Theory and New Evidence from City-Level Data. China Economic Quarterly, 3, 1145-1171.

[21] Yao Y. and Zhang M.Y. (2013) Performance of Officials and the Promotion Tournament: Evidence from Chinese Cities. Economic Research Journal, 1, 137-150.

[22] Huang, Y.S. (1996) Central-Local Relations in China during the Reform Era: Economic and Institutional Dimensions. Word Development, 24, 655-672. http://dx.doi.org/10.1016/0305-750X(95)00160-E

[23] Easterly, W. (2005) The Elusive Quest for Growth: Economist's Adventures and Misadventures in the Tropics. China Citic Press, China.

Submit or recommend next manuscript to SCIRP and we will provide best service for you:

Accepting pre-submission inquiries through Email, Facebook, LinkedIn, Twitter, etc. A wide selection of journals (inclusive of 9 subjects, more than 200 journals)

Providing 24-hour high-quality service

User-friendly online submission system

Fair and swift peer-review system

Efficient typesetting and proofreading procedure

Display of the result of downloads and visits, as well as the number of cited articles

Maximum dissemination of your research work

Submit your manuscript at: http://papersubmission.scirp.org/ 